Article by an MPIfG researcher

Renate Mayntz: Socialist Academies of Sciences: The Enforced Orientation of Basic Research at User Needs. In: Research Policy 27(8), 781-791 (1998). Elsevier

The original publication is available at the publisher's web site: http://dx.doi.org/10.1016/S0048-7333(98)00090-0

\title{
Socialist academies of sciences: the enforced orientation of basic research at user needs
}

\author{
Renate Mayntz \\ Max-Plank-Institut fur, Gesellschaftafroschung, Paulstr. 3, 50676 Koln, Germany
}

\begin{abstract}
In the former socialist societies, science was considered an instrument of socialist development and subjected to central planning procedures similar to those used in economic planning. Basic research, but also problem oriented and even some applied research was concentrated in the National Academy of Sciences. To ensure the orientation of academy research on user needs, and particularly on the needs of the socialist economy, academy institutes were required to earn a certain proportion, often more than half of their funds, by acquiring contracts from industry. The limited absorptive capacity of industry especially in the 1980s impaired the effectiveness of this forced linkage. The article traces the effects this had on academy research as a whole. (C) 1998 Elsevier Science B.V. All rights reserved.
\end{abstract}

Keywords: Academy of Sciences; Contract research; Research planning

\section{Introduction: the problem and the data base}

In the former socialist states of Central and Eastern Europe (CEE countries), scientific research was subjected to central planning and required to orient itself at the needs of a developing socialist society. A retrospective analysis of the means used to achieve such an orientation, and the effects this had on the development especially of basic research, should make a valuable contribution to a comparative study of the linking mechanisms connecting theory (scientific research) and practice, and their effects on scientific development. The opportunity for such an analysis is afforded by a number of empirical studies, which, though they did not specifically deal with this particular problem, can nevertheless serve as data base for this paper. The most important one among these studies was conducted, upon my initiative, by Werner Meske and Jochen Gläser (Gläser and Meske, 1996); it deals with the relationship between basic and applied research in institutes of the former Academy of Sciences of the German Democratic Republic which were engaged in work relevant to industry. More wide-ranging, but considerably less detailed information is supplied by the work of a network of scholars from the CEE countries who studied, under the coordination of Peter Weingart, Uwe Schimank and myself, the changes undergone by extra-university research, particularly research conducted in the national academies of sciences, in their respective countries in the course of their political and economic transformation. The first publication issuing from this project contains detailed country reports (Mayntz et al., 1995). A sec- 
ond, publication contains the results of the systematic, comparative analysis of more than 30 case studies of selected academy institutes and their fate in the course of transformation (Mayntz et al., 1998).

\section{The role of science in socialist society}

One of the basic structural characteristics of the science system in socialist countries has been the concentration of state-financed basic and problemoriented research in national academies. While in the Western tradition, academies were primarily, and have largely remained, learned societies, in socialist countries the term signified large research establishments of national scope. The largest and most prestigious of these has always been the National Academy of Sciences, normally comprising research institutes from a wide range of disciplines, from physics, chemistry and electronics to various social sciences. In addition, there often existed some more specialized academies, e.g., for agriculture, medicine, or architecture.

The academy form of research organization is a Soviet invention, but as such it expresses a more general trend, i.e., the growth of non-university research institutions that gained momentum in developed industrial societies in the twentieth century. These new research establishments were to bridge the perceived gap between university research that was increasingly constrained by teaching, and the growing sector of applied research in industry. This trend manifested itself in different forms. In Germany, it led to the foundation of the KaiserWilhelm-Gesellschaft, today's Max-Planck-Gesellschaft, in 1911-a private law association of research institutes that was initially financed by private and state contributions, but is today largely state-financed. In the highly developed Western industrial countries, academies typically continued to exist as learned societies, while state-supported non-university research organizations grew up outside of them. Even the English Royal Society which played a significant role in the development of the experimental natural sciences in the seventeenth and eighteenth centuries did not grow into a large research organization; instead, the promotion of basic and problem oriented basic research eventually became the task of the various British Research Councils (Braun, 1997). Even in Germany, however, the alternative option of establishing research institutes in the framework of the Prussian Academy of Sciences was discussed at the time (Vom Brocke, 1996; pp. 12-15). In fact, it must have been a natural tendency for an Academy of Sciences, traditionally a learned society that attempted to stimulate the scientific investigation of chosen topics, to strive for an infrastructure of laboratories and institutes of its own as research in the sciences became ever more demanding in terms of personnel and technical apparatus.

This tendency was also present in Russia, where at the beginning of the twentieth century, scientists pleaded for the establishment of research institutes in the framework of the Academy of Sciences that had been founded by Peter the Great as a 'society of scientists', i.e., a learned society. However, by the time of the revolution in 1917, the Russian Academy had only one research institute and five laboratories. While impressed by the 'German model' in the form of the Kaiser-Wilhelm-Gesellschaft, the new Soviet leaders for a variety of reasons chose to build up the existing academy to become the major organisation of state-financed research (Graham, 1975). By 1927 there were eight institutes; in the following 6 years, 29 major organizations appeared in the academy (ibid., p. 313). The academy model developed in Soviet Russia was subsequently extended to other Soviet republics, including the three Baltic states after they had been forcibly integrated into the Soviet Union. The various regional academies in the Soviet Union formed an interrelated and in part functionally differentiated system that was directed by the Soviet Academy of Sciences in Moscow, the former Russian Academy (the Russian Soviet Republic did then not have a separate academy). By the 1960s, this academy system contained approximately 600 research institutes (ibid., p. 325).

After the Second World War all East and Middle European satellite countries sooner or later copied the Soviet model of research organization. Most of these countries used to have academies in the form of learned societies, but their universities were still the major sites of basic research. To that extent they stood in the West European tradition. The introduction of the Soviet model of science organization, where academies served as the major institutions of 
state-financed basic research, broke with that tradition.

In 'scientific' socialism, science was considered the basis of production and planned innovation. Scientific knowledge was not of value in itself; the search for knowledge had to be justified by the role science presumably played in the process of societal reproduction and development. This view of the function of science implies a linear model linking basic research, applied research, and the application of research results in one causal chain. But whereas in Western societies, where this linear chain model had also gained prominence, the first link, i.e., basic research was considered the driving force leading spontaneously to useful applications, scientific research in the planned socialist societies was perceived to be in need of central guidance towards politically defined goals of production and useful application.

There is an evident fit between the Soviet type of research organization and the state socialist society. Centralized state control, specialization, and the concentration of like tasks in one large organization so as to avoid competition and redundancy, were the principles underlying the structure of socialist societies. In conformity with these principles, the Soviet economy was subdivided into monopolistically structured sectors dominated by large public corporations (Gaponenko et al., 1995; p. 390), a system that later became characteristic also of other socialist economies, including the German Democratic Republic (GDR). The structure of the science system in the former state-socialist countries also reflected these organizational principles.

As in Western countries, research in the socialist countries took place in three major sectors: the universities, extra-university institutes, and industry. University and extra-university research was charged with basic as well as applied tasks, while the industrial sector concentrated on applied research and development. This division of labor within the science system was still reflected in the distribution of research expenditures observed in Russia in 1990. Here, $52 \%$ of the research expenditures in the academy sector were devoted to basic and $35 \%$ to applied research, whereas $64 \%$ of the research expenditures in the branch institutes and $80 \%$ of the expenditures in inhouse industrial research were de- voted to development; research in the university sector was mainly of the applied type (62\%) (Gaponenko et al., 1995; p. 567). The organisational philosophy of socialist societies is most visible in the structure of non-university research, where the basic and problem-oriented research in nearly all disciplines was concentrated in a few big organizations subject to state control. In the GDR, for instance, over $90 \%$ of the R\&D personnel in the state sector worked in one of the academies. The largest of these, the Academy of Sciences [AdW], counted 60 research institutes and a staff of roughly 24,000 in 1989 (Mayntz, 1994; pp. 40-42). In Western countries the structure of the corresponding sector of the research system is much more differentiated, and the individual research organizations more autonomous. The industrial research sector also had some special structural features unknown in the West. The most notable of these was the existence of so-called branch institutes, organizationally independent $R \& D$ establishments serving a particular sector of the economy, e.g., pharmaceuticals, electronics, or chemicals. Such branch institutes are a feasible alternative to corporate $\mathrm{R} \& \mathrm{D}$ where the economy is organized in a non-competitive way, i.e., where the various plants belonging to the same industrial branch are combined to form one large public corporation (or stateowned enterprise).

The basic as well as the more applied research conducted by the national academies was expected to feed into industrial $\mathrm{R} \& \mathrm{D}$, health practice, and other fields of application, but academy institutes were by and large not expected to engage in development work themselves. In fact, most of the institutes belonging to the academies of sciences in the CEE countries were originally founded to perform basic research, and they were financed from state budgets for this purpose (Darvas, 1998). In the GDR, where research was classified into different categories ranging from $\mathrm{G}=$ basic over $\mathrm{A}=$ applied research to $\mathrm{K}=$ product development and $\mathrm{V}=$ process development, the AdW was expected to do only research of the $\mathrm{G}$ and $\mathrm{A}$ types, but not of the $\mathrm{K}$ and $\mathrm{V}$ types (Gläser and Meske, 1996; p. 149). As we shall see, however, this normatively expected division of labor could not be upheld, so that in the end AdW institutes engaged not only in development work, but even assumed some productive tasks. 


\section{The transformation of science into an instru- ment of socialist development}

The Soviet model of research organization was not built up from scratch, but emerged step by step not only by expansion, but also by reorganizing and relocating already existing research organizations. This of course holds true especially for the socialist satellite countries which had a more or less developed science system prior to their socialist transformation, but even the Soviet science system was not the result of implementing an initial (1917) blueprint (Graham, 1975). In the socialist satellite countries, the starting point for the research subsequently organized in the form of a national academy was in most cases an existing learned society. ${ }^{1}$ In East Germany, for example, the former Prussian Academy of Sciences was reestablished in the Soviet occupation zone under the name of German Academy of Sciences in July 1946. After the partitioning of Germany into one Eastern and one Western state, it was renamed Academy of Sciences of the German Democratic Republic-AdW. ${ }^{2}$ The transformation of the academy into a major research organization started immediately after its formal re-establishment. Following the Soviet model, existing institutes of basic and problem-oriented research were attached to the learned society, and new state-financed research institutes were subsequently established in its framework. The explicit aim was to transform the former learned society, in view of the importance of science for peaceful economic development, into an effective research center.

Not only the build-up, but also the integration of the academy into the hierarchical political control structure did not happen all at once, but was the end-point of a development characterized by a certain amount of conflict. In East Germany, the academy enjoyed a large degree of institutional independence in the beginning. For roughly the first 10 years of its existence, the members of the learned society, who formed several 'classes' according to their research fields, were officially responsible for directing the research of the institutes. In the course

\footnotetext{
${ }^{1}$ See the country reports in the paper of Mayntz et al. (1995).

${ }^{2}$ The history and development of the AdW is described in detail by Gläser and Meske (1996) (Chap. 2).
}

of subsequent reforms of the academy statute, however, the learned society became uncoupled from the research institutes. The latter were grouped together to form what was called the Forschungsgemeinschaft, to be supervised directly by the academy president. The academy as a whole was finally put under the direct control of the government (council of ministers). Step by step, as the ruling party's claim of comprehensive governance of all sectors of the emerging socialist society became practical reality, the academy, too, was integrated into the hierarchical political control structure, and mechanisms were devised to guarantee the orientation of its research work at politically defined goals.

Even in Soviet Russia, the subjection of scientific work to political control met initially with a certain resistance. The same held later for the satellite countries of the Soviet Union, where science had traditionally enjoyed more freedom. In East Germany, academy members, while acknowledging and accepting in general terms the role assigned to science in developing the socialist German society and its economy, still tended towards the traditional principles of scientific self-organization and self-government. The conflict also involved the expectation of producing research that was of practical use for the socialist state and the socialist economy. Darvas, summarizing numerous case studies of academy institutes in CEE countries, maintains that the higher prestige which basic research enjoys in the global academic culture persisted among scientists under state-socialism, and there seem to have existed some institutes, such as the Russian Institute of Theoretical Physics, which were almost exclusively engaged in curiositydriven basic research (Darvas, 1998). Nevertheless, academy researchers in all socialist countries have apparently accepted by and large the general expectation that the academy was not only to engage in basic research, but also to perform applied research, even though applied research was genuinely preferred only in a very few academy institutes (Darvas, 1998). In East Germany there persisted a controversial discussion about whether and to what extent the academy was to take on tasks defined for it by outsiders, and particularly by the presumptive users of its research results. The majority affirmed the academy's duty to supply practically relevant knowledge, but wanted to decide about the choice of topics 
themselves, and rejected a duty to engage directly in solving practical problems (Gläser and Meske, 1996; p. 83). This view gained support when it was observed that political attempts to harness the academy tightly to economic problem solving failed to produce the expected results.

In all CEE countries, the ruling socialist party expected science to make important contributions especially to the solution of the country's economic problems. These expectations were not only normative, but also cognitive: it was in fact believed that if only scientists played their part, economic growth and social progress could not but result. These cognitive expectations were contradicted by later developments, but still the normative expectations remained unchanged. In fact, the perceived deficit of growth impulses emanating from science led to increasing political efforts to harness the academy to economic development (Gläser and Meske, 1996; p. 95). Though scientists argued that to remain innovative, basic research should not be tied too narrowly to practical problem solving, politicians and representatives of industry insisted that the undeniable innovation deficits were due to an insufficient orientation of academy research, and especially basic research, at the solution of practical problems. As economic problems increased in all CEE countries in the late seventies and through the eighties, political pressure on the national academies to put more emphasis on contributing to economic problem solving increased. Everywhere new instruments were devised to attain this end. In Romania, the National Academy of Sciences was dissolved by the Ceaucescu regime in 1972 , because it had failed to produce the desired practical effects; its institutes were transformed into branch institutes and put under the direct supervision of various ministries. Leaving this extreme case out of consideration, we shall now turn to take a closer look at the mechanisms used to orient academy research at user needs, and especially economic needs.

\section{Mechanisms to orient research at economic needs}

The perennial reaffirmation of the national academy's social and economic function that was typical of all socialist countries was frequently followed by the critique that the academy did not sufficiently concentrate on problems posed by the economic and social-cultural development of socialist society. This set the stage for the introduction of ever new instruments to achieve the desired orientation. In principle, all of the main modes of governance could be used to this purpose, and were in fact employed: Hierarchical control, market principles (resource dependence on demand), normative control (solidarity), and organization (networking). In the case at hand, these controls took the shape of (1) subjection to central planning, (2) an enforced dependence on contract research and thus on potential users, (3) ideological inculcation, and (4) the institutionalization of organizational links between science and industry. There were undoubtedly differences in the mix of these instruments in the different socialist countries, though ideological inculcation and central planning were used everywhere. There were also shifts over time in the emphasis put on one or the other instrument, and the sequence of such shifts was not identical in all countries. But these differences only amount to fluctuations around a general trend that was very similar for all the countries here under review. Since the book of Gläser and Meske (1996) on the East German Academy (AdW) provides the most detailed information on the controls that were used, we shall in the following sections largely concentrate on this case.

It has already been mentioned that in the first post-war period, the East German Academy still enjoyed relative independence, and the classes of the learned society were collectively responsible for the work of the research institutes. At this time, personnel policy and committee coordination were used to reinforce the academy's applied orientation. The academy was advised to recruit preferably scholars from the natural and engineering sciences to its learned society. In addition, committees composed of scientists and representatives of industry were set up at the level of the different classes; these so-called 'sections' were to serve advisory and evaluatory functions. As at least a part of the academy members were themselves interested in applied research, these strategies did not meet with significant resistance. Ideological inculcation also took place from the early years on, not specifically within the academy context 
but in the society at large. At first, ideological indoctrination took place in a relatively diffuse way. Later this instrument of governance was institutionalized and increasingly formalized. Obligatory education in Marxism-Leninism was one aspect of this institutionalization; setting up the socialist party as a parallel control hierarchy within all sectors of society was the second aspect. Thus, the organizational hierarchy of the socialist party was replicated also within the academy, and the higher level party secretary became a member of the academy's leadership. The political control that was thus exerted not just over, but within the academy was of a generally political character. Though personnel policy, i.e., consideration of socialist 'political correctness' in the recruitment and promotion of academy scientists, was of prime importance in securing ideological conformity, the permanent political oversight served to stabilize and reinforce such conformity on the part of academy scientists and of the work they produced. This normative control affected the work of scientists in the natural and engineering sciences only marginally. In contrast, philosophers, historians, legal scholars and economists, i.e., social scientists in the wide sense of the term, were in greater danger of committing the sin of 'revisionism' or some other deviation from the ruling orthodoxy. ${ }^{3}$

The two major control instruments affecting the choice of specific research topics and hence also the basic or applied orientation of research in the AdW were central planning and financial dependence on contract research. Central planning became feasible only after the academy had been subjected to full political control. The requirement for academy institutes to earn part of their budget by doing contract research also served as a control instrument, but at least in some of the CEE countries there were also financial reasons for it. Thus, Darvas (1998) observes that due to fiscal problems, the prevailing high rate of government subsidy to the national academies could not be maintained during the 1980s, so that even institutes engaged in basic research were expected to find external sources of income from

\footnotetext{
${ }^{3}$ This has been documented in detail by the work of a study group of the Berlin-Brandenburgische Akademie der Wissenschaften; see Kocka and Mayntz (1998).
}

contract work. In the East German Academy, most of the basic research or G-type projects, but also part of the applied research was financed by the academy (budget financing). In contrast, most of the applied, or A-type projects were financed through contracts, but also some of the basic research. At one time, the money for budgeted projects was paid out directly by the Ministry of Science and Technology, but most of the time it was channelled through the academy presidency.

Hierarchical political control over the academy was normally not exercised by commanding the scientists what kind of research to do or topic to choose, a point also emphasized by Darvas (1998) for the academies in other socialist countries. Before the central planning system was in place in East Germany, i.e., while the academy still enjoyed a certain measure of independence, the government had defined special targeted programmes, so-called Staatsaufträge, and charged selected members of the academy's learned society with responsibility for their fulfilment. The planning system that was later devised ${ }^{4}$ consisted of a short-term (1 year) and a middle range ( 5 years) planning process; for basic research the planning horizon was at times even longer (Gläser and Meske, 1996; pp. 115-118). These processes followed by and large the same procedure as economic planning. When the academy had been fully integrated into the overall hierarchical control system, the planning levels in the science system and those in the economic system paralleled each other, which was expected to ease coordination.

The planning process started at the top. The political leadership formulated research priorities, though in highly general terms such as basic societal and economic needs; these priorities served to orient the definition of research proposals. All research had to be given the form of projects, with a specific topic, specified resource needs, and estimated completion date. The research proposals themselves were formulated by individual researchers and research teams, to be aggregated first at the level of the institute, and subsequently at academy level. In this bottom-up process of aggregation, selections (rejections, modi-

\footnotetext{
${ }^{4}$ For the following see Gläser and Meske (1996) (Chap. 3).
} 
fications) took place both at the institute and the academy level. The political authorities largely abstained from defining specific research topics, but reserved for themselves the right of final approval, and thus the ultimate selective function. In fact, however, the anticipation of selection at the next higher level in the planning process produced enough 'voluntary' alignment with the expected selection criteria that the outright rejection of research proposals did not happen very often. But when the plan was finally approved by the political authorities, it became the binding framework for the work of the institutes, and served to evaluate their subsequent performance.

Turning to the second of the above-mentioned control instruments, contract financing, the expectation that the AdW should earn part of its income by doing contract research had been formulated very early on. Later, this requirement was expressed as a specific percentage of contract financing to be achieved. Increased pressure on the academy sometimes took the shape of increasing this percentage. The required amount of contract work varied between institutes, and within institutes, between research units, thus taking into account the greater or lesser likelihood to 'sell' research of different kinds and in different disciplines. In the end, however, the target set for each institute and for the academy as a whole had to be met. The actual share of contract financing by users varied from year to year. It went up to as much as two thirds of total academy expenditures in some years (Gläser and Meske, 1996; p. 121). The largest share of contract money came from industry (up to nearly $60 \%$ of total research expenditure). The large public corporations (Kombinate) were required to form special funds to pay for contract research. This money, incidentally, did not go only to academy institutes; contracts were also given to universities. There were also special state subsidies specifically earmarked to pay for contract research. In a way, and since the corporations were themselves state-owned, contract financing of academy research was therefore not a matter of true market demand, but an indirect way of state-financing which was expected to bring the actual research needs of different branches of the economy to bear on the academy. One could therefore speak of control by target groups or beneficiaries, an instrument for obtaining a fine-grained adjustment to demand such as no central planning can achieve. This form of establishing target group control over research in the state sector is also used in non-socialist countries; in (West) Germany for instance the public funds which the institutes of the Fraunhofer Gesellschaft receive are linked to their success in acquiring contract money. In the case of East Germany, contract financing and central planning were complementary means of control.

In East Germany, two complementary types of contract were used. One type, called Koordinierungsverträge, was meant to establish a long term cooperation between specific research fields and those areas in economy and society that might use their results. Such contracts were normally concluded at the branch level, i.e., by the Kombinat in which the firms of a given branch, sub-branch or specialization were organized. This kind of contract could well include a substantial amount of basic research that was problem-oriented only in a general way. The second kind of contract, so-called Wirtschaftsverträge, was concluded at the plant level and involved applied research concerning specific problems or demands. It was the combination of these two types of contract which was assumed to orient academy research as a whole at practical needs. In the 1980s, an additional financial instrument was introduced to increase the acceptance of contract research among scientists: financial inducements paid to individual researchers working on contract projects. However, this utilitarian undergirding of a persistent normative pressure does not seem to have had a strong (additional) impact.

Especially where contracts of the second, more practical and short-term type were concerned, the contract was not only supposed to specify the expected outcome in general terms and to name the time and the amount of personnel to be used for its completion. It was also demanded that the transfer of the expected research results into daily production, and the economic value of the resulting innovation, were to be written into the terms of the contract. In view of the inherent uncertainties in research, and the unpredictable scope for innovation in industry, neither of the two contract partners accepted this requirement easily. The contract was complemented by a so-called Pflichtenheft, a detailed, step-wise 
programming of the resources to be employed, dates to be met, tasks to be performed, and outcomes expected at the end of each step. This planning requirement, i.e., to formulate and then to follow what was put down in the Pflichtenheft, held not only for contract research but also for budgeted projects. Work on a contract project was accompanied by frequent informal contacts between academy and industrial researchers, but there was also a series of highly formalized presentations and discussions of progress made and of results obtained that was demanded of all academy projects (Gläser and Meske, 1996; pp. 297-299). In principle, and if it is possible at all to orient research at practical needs, this elaborate system of steering mechanisms should have resulted in a stream of usable inventions and subsequent innovations. However, this is not what actually happened.

\section{How the model worked in practice and why it failed}

If the readiness on the part of science to orient research at external demands is in fact the outcome of the system of controls just described (which is not necessarily true, if scientists succeed to evade the controls or learn to manipulate the system to their own advantage), the way in which the system actually works depends obviously on the kind of demands articulated. In all socialist countries, the demands of industry played the dominant role, but there may have been differences in the relative importance of different branches. In the Soviet Union, where $71 \%$ of the overall $\mathrm{R} \& \mathrm{D}$ expenditures went into military research, the defense industry was the major client of many, if not most academy institutes in the Soviet republics of Russia, Belarus, Ukraine, and the Baltic states (Gaponenko et al., 1995; p. 70; Darvas, 1998). In East Germany, demands of the defense industry appear to have played a less dominant role for the academy, but as contract research for the military was not officially classified as such, ${ }^{5}$ this cannot be stated more exactly. But whichever

\footnotetext{
${ }^{5}$ Written information by Jochen Gläser.
}

branch of industry formulated the concrete demands, the crux of the matter was that industry in East Germany as well as in most socialist satellite countries was not ready to absorb innovative research outputs. In the GDR, stress was laid in the immediate post-war period on reconstructing the traditional heavy industries, a task for which significant inputs from science were not needed. Later, as the planned economy and the isolation from international markets produced growing problems for the state-socialist economies, the demands for innovative inputs remained low because now all available forces were needed to meet the annual production plan.

The detailed information we have about the German case permits to observe the consequences this had for research that was of potential relevance to industry. One consequence was an asymmetric interdependence between academy and industry in the contractual relationship. The initiative for concluding a contract could come from both sides, and both partners, in principle, could refuse the offer. In fact, however, the academy needed contracts more than industry needed its research outputs. Research teams from the academy therefore had to try actively to sell their projects to industry, and if the percentage of contract financing expected from a specific research unit was not yet met, the pressure to accept any kind of offer irrespective of its inherent scientific interest was strong.

The East German economic production system, strained to the utmost to meet present output expectations, lacked both the means of investment and the organizational slack needed to engage in significant product or process innovations. As a consequence, industrial $\mathrm{R} \& \mathrm{D}$ units were increasingly charged with production support and repair tasks, which left little room for development work, let alone problem-oriented basic research. In fact, the latter tended to disappear completely from industrial research. In this situation, industry was interested to have the academy take over the tasks that their own R\&D units could no longer perform. But innovative research outputs whose utilization would require investments and involve risks were not needed. The research outputs that industry did ask for were of three types: (1) means to increase productivity by rationalizing ongoing production processes, (2) the re-invention of product and process innovations that were already 
used in the West, but not available to the local industry because of embargo restrictions, and (3) the solution of acute problems in ongoing production (fire engine functions). Innovations were only accepted if they met three conditions:

- they had to be risk-free, i.e., already tested on more than a laboratory scale;

- they should require neither special machinery nor substantial investments and time to build up; and/or

- they must concern products that were needed to meet defined ends and thus fitting into the overall national production plan.

Forced to acquire contracts, and faced by this kind of external demand, the academy gradually built up its own technological capacity. In particular, a large institute specialized in constructing (developing and producing) all kinds of scientific instruments and apparatuses, the Zentralinstitut für wissenschaftlichen Gerätebau was established. Its primary function was to supply the academy institutes with the needed research infrastructure, an internal service function that can be observed to some extent in most large research establishments but that became increasingly important in the GDR as the difficulties in obtaining scientific instruments on the (largely Western!) market grew. Universities and industry, however, were also supplied with products from this Zentralinstitut, and a certain (decreasing) part was even exported. ${ }^{6}$ Other institutes produced certain materials, e.g., special chemicals or test materials for the pharmaceutical industry. All this was in evident violation of the academy's functional identity. In spite of the fact that the academy was originally expected to perform only tasks of basic and applied research, its work shifted increasingly into the direction of product and process development.

After the signing of a contract, there followed typically no joint research work; instead there was a clear division between producers (academy researchers) and consumers (industry). This relationship was particularly difficult where the industrial partner had no R\&D capacity of its own. Where, instead, the industrial partner was represented by industrial researchers, the academy team could count

\footnotetext{
${ }^{6}$ Written information by Werner Meske.
}

on a better understanding for the scientific issues touched by the project, and for the manifold problems arising in its course.

\section{Consequences for basic research}

The increasingly narrow practical demands that industry addressed to the East German Academy could not but diminish the innovative potential of its research, at least where this was subject to the pressures for application. The tendency to derive research tasks increasingly from actual production problems hinders science in discovering new chances of technological innovation. This was recognized and emphasized over and over again by scientists, and intermittently it was also acknowledged in science policy, but this did not permanently diminish the political pressure on the AdW.

As time went on, two parallel and interconnected developments took place. The share of basic research decreased generally, and the kind of basic research still conducted in the more applied fields changed. ${ }^{7}$ The decrease in the share of basic research had two different aspects. One aspect was the reduction of research in fields that are, or appear, inherently devoid of any practical application, now and in the future. Over time, less money was allocated to many of these research fields. ${ }^{8}$ Direct political intervention did not play a significant role in this reduction. More important was the fact that normally no contract financing was available for basic research which had no practical implications even in a long-term perspective. This kind of basic research was supposed to be financed out of the normal academy budget. But, as pointed out before, the bottom-up planning process to which all research was subject had to orient itself at what were considered basic societal and economic needs. By anticipating the selection criteria that would be used at the next higher planning level, research proposals that could not easily be related to the overarching political goals were less likely to be made. Of course, whether a certain research field can or cannot be related to

\footnotetext{
${ }^{7}$ This is described in detail by Gläser and Meske (1996) (Chaps. 8 and 9).

${ }^{8}$ This has been confirmed by the case studies in Kocka and Mayntz (1998).
} 
basic societal or economic needs is to a certain extent a matter of interpretation, and this chance was certainly used by the researchers in drafting their project proposals. Thus, a certain degree of autonomy in defining basic research topics was in fact preserved, and this seems to have held for the academies in all of the socialist countries.

The reduction of basic research affected also fields where research did have potential practical relevance. Here the planning procedure favored selectively projects that expressly aimed at useful results, even if only in a long-term perspective. Additional restrictions derived from the fact that such research was of the kind for which it should have been possible to acquire external funds. But if a contract was indeed sought and obtained, the basic research content of the project often had to be de-emphasized in favor of more applied aspects. Where the pressure was high to solve a practical problem, it was also more important to meet certain specifications of practical importance, e.g., product qualities such as viscosity or electrical resistance, than to ask for the causal relationship underlying an observed relationship between the property in question and, say, the molecular structure of a compound-not for lack of scientific curiosity, but for lack of time and free work capacity. Irrespective of the fact, illustrated by one of the case studies of Gläser and Meske (1996), that a mutually beneficial relationship between basic and applied research could occasionally be observed, the overall result was a gradual 'crowding out' of basic research by the pressures of contract financing where costly and risky innovations were not asked for. Schimank (1998) similarly speaks of 'scientific burn-out' as a consequence of having to do applied research while being forced to accept whatever contract was being offered.

Different from such crowding-out processes of basic research at the project level, crowding out took also place at the research unit level. Here crowding out resulted if a contract project in a research unit that conducted also academy-financed basic research required more resources than anticipated and the contract paid for, so that the scientists doing basic research were forced to help with the applied project. But even where basic research was not diminished, its very nature did not remain unaffected. Where basic research continued to be per- formed in fields of potential practical relevance and in units also doing contract research, a tendency was observed to keep the chances of future applications in mind in the choice of problems. Thus, there was a selective pressure in these units to concentrate on basic research that appeared capable of feeding into, or giving rise to applied research. The consequence was a decreasing level of abstraction and degree of theoretical generalizability. In the eighties, this tendency affected most of the basic research in AdWunits doing work relevant to industry (Gläser and Meske, 1996; p. 348).

Another consequence of the pressures of contract research was the increasing disintegration, or uncoupling of applied from basic research in fields where both were conducted. This happened where a research unit, after concluding one applied project, was not permitted to return to basic research, but forced to start work on another contract posing narrow practical problems. In such cases, the unit lost its contact with developments in basic research, whose share dwindled and finally disappeared from the unit's work-which is especially true because, as Gläser and Meske (1996) (p. 342) point out, basic research in fields of potential practical relevance leads more easily to applied projects than the other way round. With an increasingly applied orientation, there also went hand in hand a loss of continuity in research lines. While basic research often takes the shape of a long series of interlinked steps, an applied project rarely gives rise to another applied project of the same sort (Gläser and Meske, 1996; p. 322).

Having pointed out the consequences of forcing research to orient itself at external demands and politically defined goals, it should be emphasized in conclusion that to urge a basic research organization to do also applied work will not inevitably erode creative scientific work. Much depends on the kind of external demands made of science. For a fruitful coexistence of basic and applied research in one organization to be possible, the demand for applicable results should not focus on narrow practical problems, but ask instead for the development of scientific knowledge generally in a circumscribed field of industrial, medical or other kinds of practice. For basic research not to be crowded out by applied research-something that also happens in Western publicly funded institutes serving a dual pur- 
pose ${ }^{9}$ - only part of the personnel of a research unit should be engaged in applied work at any one time. Thus, there should be maintained a continuity of basic research in the unit. A final condition is the interest of scientists actually to do basic research. This condition seems to have been met even in the socialist countries considered here, in spite of the socialization of scientists into a materialistic world view. But though necessary, this subjective motivational factor is not a sufficient condition for the maintenance of a mutually stimulating relationship between basic and applied, endogenously and exogenously generated research. The findings presented here are not characteristic only of past socialist societies (Mayntz, 1997). We can presently observe manifold attempts to orient basic research more specifically at user needs, which also challenges the institutional division of labor between different research types that has characterized the (West) German science system. In this general context, the fate of research in the socialist academies of sciences might sound a warning note.

\section{References}

Braun, D., 1997. Die politische Steuerung der Wissenschaft. Ein Beitrag zum 'Kooperativen Staat'. Frankfurt am Main, Campus.

\footnotetext{
${ }^{9}$ A classical example is the German Physikalisch-Technische Reichsanstalt; see Hohn and Schimank (1990) (pp. 64-72).
}

Darvas, G., 1998. In: Mayntz, R., Schimank, U., Weingart, P. (Eds.), Identity Problems: Basic or Applied Research?, Chap. 5 , op. cit.

Gaponenko, N., Gokhberg, L., Mindeli, L., 1995. In: Mayntz, R., Schimank, U., Weingart, P., (Eds.), Transformation der Wissenschaft Rußlands. op. cit., pp. 382-569.

Gläser, J., Meske, W., 1996. Anwendungsorientierung von Grundlagenforschung? Erfahrungen der Akademie der Wissenschaften der DDR. Frankfurt am Main, Campus.

Graham, L.R., 1975. The formation of Soviet Research Institutes: a comparison of revolutionary innovation and international borrowing. Social Studies of Science 5, 303-329.

Hohn, H.-W., Schimank, U., 1990. Konflikte und Gleichgewichte im Forschungssystem. Akteurkonstellationen und Entwicklungspfade in der staatlich finanzierten außeruniversitären Forschung. Frankfurt am Main, Campus.

Kocka, J., Mayntz, R. (Eds.), 1998. Wissenschaft und Wiedervereinigung. Disziplinen im Umbruch. Berlin, Akademie-Verlag.

Mayntz, R., 1994. Deutsche Forschung im Einigungsprozeß: Die Transformation der Akademie der Wissenschaften der DDR 1989-1992. Frankfurt am Main, Campus.

Mayntz, R., 1997. Forschung als Dienstleistung? Zur gesellschaftlichen Einbettung der Wissenschaft. Berlin-Brandenburgische Akademie der Wissenschaften. Vol. 3, Berichte und Abhandlungen, pp. 135-154.

Mayntz, R., Schimank, U., Weingart, P. (Eds.), 1995. Transformation mittel- und osteuropäischer Wissenschaftssysteme. Länderberichte. Opladen: Leske und Budrich.

Mayntz, R., Schimank, U., Weingart, P. (Eds.), 1998. East European. Dordrecht, Kluwer, Academy in Transit.

Schimank, U., 1998. In: Mayntz, R., Schimank, U., Weingart, P. (Eds.), What Determines an Institute's Fate in Transformation? op. cit.

Vom Brocke, B., 1996. Die Kaiser-Wilhelm-/Max-Planck-Gesel1schaft und ihre Institute zwischen Universität und Akademie. Strukturprobleme und Historiografie. In: Idem, Laitko, $\mathrm{H}$ (Eds.), Die Kaiser-Wilhelm-/Max-Planck-Gesellschaft und ihre Institute. Studien zu ihrer Geschichte: Das Harnack-Prinzip. Berlin/New York, de Gruyter, pp. 1-34. 